\title{
Discourse Markers in News Articles of the Jakarta Post
}

\author{
Yulianto ${ }^{1}$ \\ ${ }^{1}$ Universitas Islam Riau \\ email: yulianto@edu.uir.ac.id
}

\begin{abstract}
Discourse markers facilitate text interpretation. Discourse markers (DMs) were key attributes in linking sentences, rendering the text coherent. This study aimed to analyze Discourse Markers (DMs) found in four News Articles of The Jakarta Post based on Halliday and Hasan point of view. They were additive, adversative, causal and continuative. The writer used a descriptive qualitative method, in which the data were sentences that contain discourse markers in the articles. The data were analyzed by applying the theory of discourse markers from Halliday and Hasan (1976). The result showed there were 21 discourse markers found in four news articles. All the news articles included additive, adversative, causal, and temporal/continuative discourse markers. In the Jakarta Post news article, the numbers of the discourse markers were ample for readers to understand the articles better.
\end{abstract}

Keywords: Discourse Markers, cohesion, coherence

\begin{abstract}
Abstrak
Penanda wacana memfasilitasi pembaca dalam interpretasi teks. Penanda wacana (DM) adalah atribut kunci dalam menghubungkan kalimat, sehingga membuat teks menjadi koheren. Tujuan penelitian ini adalah untuk mengetahui Penanda Wacana (DM) yang terdapat pada empat Artikel Berita di Jakarta Post berdasarkan sudut pandang Halliday dan Hasan: aditif , adversatif, kausal dan kontinatif. Penulis menggunakan metode deskriptif kualitatif, dimana datanya berupa kalimat-kalimat yang mengandung penanda wacana dalam artikel. Data dianalisis dengan menerapkan teori penanda wacana dari Halliday dan Hasan. Hasil penelitian menunjukkan terdapat 21 penanda wacana yang ditemukan di empat artikel berita. Semua artikel berita mengandung penanda wacana aditif, adversatif, kausal, dan temporal / kontinatif. Kecukupan penanda wacana dalam artikel berita di Jakarata Post cukup memadai bagi pembaca untuk dapat memahami artikel dengan baik.
\end{abstract}

Kata Kunci: Penanda Wacana, Kohesi, Koherensi 


\section{INTRODUCTION}

Language is a central human instrument in the communication process. Language can be defined as a system of arbitrary vocal symbols used by human communication. The use of language by people worldwide can be in the form of spoken and written discourse. There are two types of language as a means of communication, spoken and written discourse.

Halliday and Hasan (1976) claimed the linguistic use of the text referring to some passage, whether written or spoken. This means that a text can be analyzed in many forms, not only in the form of a spoken text, such as conversation, speech, and film, but also in the form of a written text, such as mass media, newspaper, and magazine. In addition, texts must contain certain characteristics, particularly a coherent texture, to establish a linked and well-structured expression so that it can be easily understood.

The news is one of the press media, which has a means of communication. Factual information about current affairs is news. Many outlets publish news, including newspapers, magazines, TV shows, cable and radio programs, blogs, email messages, and word of mouth. The article in the press is an article on a current case. The details of the case are reported in this article; the author does not include his or her views.

We may find a linked sentence in the text with another one. The related term can be called cohesion. Halliday and Hasan (1976) have also suggested that harmony is part of the language structure. The capacity of continuity lies in the relation, ellipsis, and the similar synthetic tools built into the language itself. Cohesion is represented by the alignment of language strata. Language can be defined as a multiple coding scheme comprising three coding or layer levels; the semantic "meaning," lexicogrammatical "forms," and the "expression" phonological orthographic. It means that cohesion will make the reader or the listener easily understand the text in spoken or written.

The tools in cohesion are called as the cohesive devices/ discourse markers. They are words, utterances, phrases that occur to connect one entity with the other entity in the text.

A discourse marker is a term or an expression that plays a role in the management of discourse flow and structure.

As their primary role is at the discourse level (sequences of utterances) rather than at the level of utterances or words, discourse markers are largely independent of grammar and do not generally modify the sentence's true conditional meaning. The particles, yeah, well, now, then, you see, and I mean, and the discourse relations so, since, and, but, and or, are examples of discourse markers.

In different areas, including Discourse Analysis, Conversation Analysis, Pragmatics, Semantics, Syntax, and Computational Linguistics, and others, Discourse Markers' issue has caught the interest of many scholars.

This linguistic element has been labeled using different terms (Das \& Taboada 2018; Beeching, K., \& Detges, U. 2014; Dor 2010; Fraser 1999; Schiffrin 2005) both across the various fields in which they are studied, as well as within the same field: discourse markers, discourse particles, discourse connectives, pragmatic markers, cue phrases, hedges, and so on.

Connectives have also been referred to as conjunctive expressions (Halliday \& Hasan, 1976), pragmatic markers (Fraser, 
1990), connective discourse (Blakemore, 1987), and lexical signals, typically in the area of memory and understanding. The word discourse markers will be used in this paper as a synonym for all words above because of the variant names given to this group of linguistic types, as it has now become more likely to appear in recent studies as a prototype term to include any lexical form that has the purpose of linking segments of text (e.g. Blakemore, 2005; Schiffrin, 2005; Taboada, 2006).

\subsection{Discourse Analysis}

Discourse analysis is the analysis of spoken language and written language analysis. Paltridge (2006) claims that discourse analysis is an approach to language analysis that explores language trends through texts as well as the social and cultural contexts in which the texts take place. Discourse research is used to evaluate what the terminology is used for (Yule, 1983: 1)

There are two forms of discourse: speech that is written and voiced. Voice, speech, etc. are forms of spoken discourse, while newspapers, journals, and books are written discourses. Discourse spoken as speaking is disorganized and written discourse is written grammatically. Spoken discourse is always created randomly, and when someone speaks, we can see the mechanism of its creation (Paltridge 2006: 17).

Discourse refers to the set of language-tocontext standards, preferences, and expectations that language users draw on and modify when producing and making sense out of the context of language. Awareness of discourse enables language users to establish and understand systems of discourse such as linguistic actions (e.g. demands, offers), conversational sequences (such as questionanswer), behaviors (such as narrative and arguing) and communication forms (such as the voice of women). It means that discourse relate to speech or piece of writing which makes the language user produces discourse through verbal act, conversation or communication.

Widdowson (1979) also claimed that teachers normally do not pay much attention to teaching how to relate sentences together to form related discourse parts. Teachers depend on grammar to connect phrases and treat phrases as separate units.

Widdowson (1979) has also thought that teachers generally do not pay much attention to teaching how to relate sentences together to form stretches of connected discourse. Teachers rely on the grammarian to connect the sentences and they consider sentences as distinct units. Louwerse and Graesser (2005, pp. 1-2) argue that, "The term discourse was reserved for dialogue several years ago, and text was reserved for monologue." The discourse encompasses both monological and dialogic spoken and written language in contemporary science.

\subsection{Text}

Text is the verbal record of the communicative event. (Brown and Yule, 1983:190) It means that text is relating to words to keep a permanent account which obtained from speaking. Actually, text is not only speaking but also writing. According to Halliday and Hasan, the word text is used in linguistic to refer to any passage, spoken, or written, of whatever length, that does form a unified whole.

A text may be defined as a real use of language, apart from a term that is an abstract unit of linguistic study (Widdowson, 2007:4). 
Although a text is not just a series of phrases, Halliday and Hasan state, in other words, it is not necessarily a broad grammatical unit, anything of the same nature as a phrase, but different in scale. Two types of text exist: spoken and written text. Spoken text is the utterances created by individuals such as speech, conversation, etc., whereas written text is a text generated by writers such as newspapers, journals, books, etc. Spoken text is often ungrammatical since the spoken text relies on the utterances of the speaker. Although written text is more grammatical, discourse relations such as coherent instruments used in text and the meaning of text are more oriented.

\subsection{Coherence and Cohesive Devices}

Dulger (2007) has stated that from word to sentence and from sentence to paragraph, a writer follows a coherent composition. Sentences are bound by unified instruments, and Dulger mentions that a coherent text has a seamless flow in which sentences quickly accompany each other. He added that to achieve the interpretation of the text, readers use syntactic and structural relations. In addition to punctuation and composition, in written discourse and above sentence level, discourse markers assist writers to connect sentences to form a paragraph and paragraphs to form a text. Hussein (2006) has proposed that DMs are called linguistic instruments by the coherence community. He also adds that by linking multiple sections of a text, DMs cause coherence in the text.

Halliday and Hasan (1976) regarded a text's accuracy as a well-formed text. They also assume that continuity is a linguistic method by means of which we can connect a text's units such that the text remains coherent. By using co-reference, ellipsis, and conjunctions, a text can be coherent. Five types of English cohesive devices were also represented: They are reference, substitution, ellipses, conjunction, and lexical cohesion. Halliday and Hasan viewed relation or connective elements as markers of discourse; some types of discourse markers are:

1. Additive markers: and, or, also, in addition, furthermore, besides, similarly, likewise, by contrast, for instance, etc.

2. Adversative markers: but, yet, however, instead, on the other hand, nevertheless, at any rate, as a matter of fact, etc.

3. Causal markers: so, consequently, it follows, for, because, under the circumstances, for this reason, etc.

4. Temporal/Continuative maskers: before, now, while, of course, well, anyway, surely, after all, etc.

They also pointed out that it can be recognized as a text if sentences are semantically related by the use of coherent instruments. Thus, the concepts' texture 'and' cohesion 'are closely interrelated. Cohesion was divided into two forms by Halliday and Hasan (1976): grammatical cohesion and lexical cohesion. For grammatical cohesion, the most familiar category is discourse markers. Hussein (2006. p. 3) has referred to some examples for DMs:

a. John has got a really good math exam rating on him.

b. And, last of all, he was the first in his class. (additive)

c. Yet, this word, he failed his syntax exam. (Adversative)

d. He feels very depressed now, and he is worried about leaving school. (temporarily)

Hussein (2006, p. 3) stated that through repetition or reiteration, lexical continuity can 
be achieved. There was a great woman who, when I was a boy, used to look after me. She used to feed me, play with me, and tell me stories that were cool. The woman was a mother of mine.

\section{METHOD}

In this study, the writer analyzed four news articles in the Jakarta Post as the data to analyze. This study employed descriptive qualitative in form of content analysis and library study because the writer analyzed discourse markers in news article of Jakarta Post. Qualitative study is a kind of study in which the method of data collection is nonexperiment and the type of data is qualitative and the way to analyze the data is interpretive.

The ways to collect the data are: the first step is writer read the four news articles as data for this study repeatedly. Second, writer marked that word with their criteria given by the writer. Third, writer wrote the types of each discourse markers beside the sentences in news articles. Fourth, put all of sentences in table or tabulate the data. The fifth, writer identified the data based on each type of discourse markers. Sixth, identify the data and write the number of each datum in tables. The writer classified each datum based on words from the datum that have type of discourse markers. The last step is drawing conclusion of the using of discourse markers in four news articles of Jakarta Post.

For the technique of data analysis, the researcher adopts the framework developed by Miles and Huberman (2014) to describe the major phases of data analysis: data condensation, data display and drawing conclusion.
In this study, there is no data reduction because all data are used. The steps of analyzing the data as follows:

1. Reading the sentences.

2. Marking the discourse markers.

3. Analyzing the discourse markers by using Halliday and Hasan theory.

\section{FINDINGS AND DISCUSSION}

This part describes about the findings, discussion and analysis of discourse markers in four news articles of the Jakarta Post newspaper. The writer uses

discourse markers theory proposed by Halliday.

\section{Finding}

News article 1 entitled Jakarta extends COVID-19 state of emergency to April 19. Then, news article 2 entitled COVID-19: 'Mudik' ban to begin Friday, roads to remain open. Next, news article entitled Health minister issues new protocols for public activities. The last news article entitled Indonesia records another record number of new COVID-19 cases.

\section{Discourse Markers in news article of the Jakarta Post}

\section{a. Additive Markers}

The additive DMs is somewhat different from coordination proper, although it is no doubt from it. The following are three examples of additive DMs in news articles which are displayed into tables. 
Table 1: Additive Markers.

\begin{tabular}{|c|l|}
\hline Data & \multicolumn{1}{c|}{ Sentences } \\
\hline Data 1 & $\begin{array}{l}\text { The decision was made during a meeting involving the provincial administration, the Jakarta Police and the } \\
\text { Kodam Jaya military command on Saturday. }\end{array}$ \\
\hline Data 2 & $\begin{array}{l}\text { He said the stay-at-home instruction and closure of schools and tourist destinations would also be extended to } \\
\text { April } 19 .\end{array}$ \\
\hline Data 3 & $\begin{array}{l}\text { The provincial administration also urged Jakarta residents to not leave the city to return to their respective } \\
\text { hometowns for mudik (exodus). }\end{array}$ \\
\hline
\end{tabular}

The word "and" in data 1 has a function to connect between first sentence, "The decision was made during a meeting involving the provincial administration, the Jakarta Police "and the second sentence "the Kodam Jaya military command on Saturday. The word "and" in the sentence give an explanation to the readers that the decision was made during a meeting involving three parties - the provincial administration, Jakarta police, and Kodam Jaya military - as an effort to contain the COVID-19 pandemic.

The word "and" and "also" in data 2 has function of continuing with the same idea and is going to provide additional information.

The word "also" in data 3 contributes to give additional information without changing information in the previous phrase or clause.
Based on the explanation above, additive discourse markers that used in all data have a same function to give addition in the sentence. Besides, additive discourse markers in the sentence can gives support the preceding sentence to make the readers more understand about the sentence. That is to say the writer is continuing with the same idea and is going to provide additional information.

\section{b. Adversative Markers}

The basic meaning of the adversative discourse markers is contrary to expectation. The expectation may be derived from the content of what is being said, or from the communication process. The following are examples of adversative discourse markers which are displayed into tables.

Table 2: Adversative Markers.

\begin{tabular}{|c|l|l|l|}
\hline Data & \multicolumn{5}{|c|}{ Sentences } \\
\hline Data 4 & $\begin{array}{l}\text { The government will begin its ban on the Idul Fitri mudik } \\
\text { on Friday with travel restrictions in COVID-19 red zones but it } \\
\text { completely block off roads and access to public transportation. }\end{array}$ & $\begin{array}{l}\text { (exodus) } \\
\text { will not }\end{array}$ \\
\hline Data 5 & $\begin{array}{l}\text { Despite the ban, Luhut, who is also the acting transportation minister, said public transportation across Greater } \\
\text { workers and hospital service staff }\end{array}$ \\
\hline
\end{tabular}


The word "but" in data 4 has a function to show the contrast. The writer is switching to a different, opposite, or contrasting idea than previously, The sentence explains that The ban will begin on the Idul Fitri mudik (exodus) by limiting transportation, but not for public transportation.

The word "despite" in data 5 tells a different or contrasting idea than previously. The sentence explains despite the ban, public transportations however are allowed to commute to work for medical workers.

\section{c. Causal Markers}

The simple form of causal discourse marker is expressed by so, thus, hence, therefore, accordingly, and a number of expression like as a result of a sequence. The following are examples of causal discourse markers which are displayed into tables.

Table 3: Causal Markers.

\begin{tabular}{|c|c|}
\hline Data & Sentences \\
\hline Data 6 & We were not rushing because everything must be prepared carefully and thoroughly," Luhut said \\
\hline Data 7 & $\begin{array}{l}\text { Public places have a high potential for the spread of COVID-19 since they are places for large gatherings and have } \\
\text { high mobility rates for people. }\end{array}$ \\
\hline
\end{tabular}

The word "because" in data 6 and the word "since" in data 7 indicate causal discourse markers. The writer will show a connection between two or more things, how one thing caused another, or how something happened as a result of something else. The word because is support the sentence "We were not rushing."

The word "since" has a function to show the cause in the sentence. The sentence explains that public places for large gathering and mobility rate cause of spreading of COVID-19.

\section{d. Temporal /continuative Markers}

The discourse marker between the two sentences that is, their relation in internal terms, as content-maybe simply one sequence in time. The following is example of temporal or continuative discourse marker which is displayed into tables.

Table 4: Temporal/continuative Marker.

\begin{tabular}{|c|l|}
\hline Data & \multicolumn{1}{|c|}{ Sentence } \\
\hline Data 8 & $\begin{array}{l}\text { Before the decision, Jokowi had only advised the public not to participate in the exodus and ordered regional } \\
\text { heads to find ways to discourage people from traveling, while prohibiting only government workers from going on } \\
\text { mudik trips }\end{array}$ \\
\hline
\end{tabular}

The word "before" and "while" in this sentence is arranging ideas in the order in which they happened. The word "before" is used to explains the time when Jokowi advises the public and orders regional heads to discourage public from travelling. The word "while" is used to gives support in the first sentence as a signal of the time. 


\section{Discussion}

The analysis of discourse markers in written text is the important thing that writer must use it. Besides connecting the sentence, discourse markers can give support and addition in the sentence, give comparison, and make the sentences simpler because little repetition and the important thing do not disturb the meaning.

Halliday and Hasan (1976) distinguish four major discourse markers, they are additive, adversative, causal, and temporal/continuative. The writer uses Halliday and Hasan theory. This theory is appropriate with the research because the source of data is some articles or texts from the Jakarta post newspaper.

Based on the analysis above, the writer found 21 discourse markers in four news articles of the Jakarta Post. Many types of discourse markers used in the article with different functions. Most of the discourse markers used in the Jakarta post newspaper articles are additive discourse markers "and", "also". These discourse markers have functions; to give addition in the sentence and support the preceding sentence.

\section{CONCLUSION}

Based on the findings and discussion of the discourse markers in news articles of The Jakarta Post, it can be concluded that discourse markers used in the news article are vary from one article to another. There are four type of discourse markers used in news articles of The Jakarta Post. They are additive, adversative, causal, and temporal/continuative
There are also adversative discourse markers, such as "but" and "despite" that tells a different or contrasting idea than previously. Another discourse markers are causal "because" and "since". These discourse markers will show a connection between two or more things, how one thing caused another, or how something happened as a result of something else.

The last discourse markers are temporal/ continuative, such as "before" and "while". They have function to arrange ideas in the order in which they happened.

Finally, to properly grasp DMs' significance in the construction of text (written discourse), the writer must use an appropriate number of discourse markers. Discourse markers enhance the coherence of a text. A text's coherence is as a basic interpretation by a reader in a text. It is a component of a transaction between text and reader-between the world of readers and authors' language.

Furthermore, as readers are familiar with various kinds of discourse markers, they can remember a text's basic structure, so it increases their interpretation of a text.

discourse markers. The enough number of discourse markers in written discourse or spoken discourse help readers and listeners understand the text better.

In accordance with the conclusion, the suggestions can be given of the following: The discourse markers should be one of the top concerns when writer want to delivers 


\section{REFERENCES}

Brown, Gillian and George Yule. 1983. Discourse Analysis. Cambridge: Cambridge University Press

Blakemore, D. (1987). Semantic Constraints on Relevance. Oxford: Blackwell.

Blakemore, D., \& Carston, R. (2005). The pragmatics of sentential coordination with and. Lingua, 115(4), 569-589.

Beeching, K., \& Detges, U. (2014). Discourse functions at the left and right periphery Crosslinguistic investigations of language use and language change. Leiden

Part 1 pg i -87

Dymock, S. (2005). Teaching expository text structure awareness. The Reading Teacher, 59(2), 177-182.

Dulger, O. (2007). Discourse markers in writing. Seluck University Sosyal Bilimler Enstitutus Dergis, 18, 257-270.

Dér, C. (2010). On the status of discourse markers. Acta Linguistica Hungarica, 57(1), 3-28.

Widdowson, H. G. (1979). Explanation in applied linguistics. Oxford: Oxford University Press
Das, D., \& Taboada, M. (2018). Signalling of coherence relations in discourse, beyond discourse markers. Discourse Processes, 55(8), 743-770.

Fraser, Bruce. 1990. An Approach to Discourse Markers.

Halliday , M. A. K. \& Hasan, R. (1976). Cohesion in English. London: Longman.

Hussein.M.(2006). Discourse markers in English.. (accessed 20/8/2010). http://star28.academia.edu/MiriHussein/ Papers/494852/TWO_ACCOUNTS_OF DISCOURSE_MARKERS_IN_ENGL $\underline{\text { ISH }}$

Louwerse, M. M. \& Graesser, A. C. (2005). Coherence in discourse. In P. Strazny (Ed.), Encyclopedia of linguistics. (pp. 216-218) Chicago, Fitzroy Dearborn.

Paltridge, Brian. 2006. Discourse Analysis: An Introduction . Britain: MPG books Ltd

Schiffrin, D. (2005). Discourse markers: Language, meaning, and context. The handbook of discourse analysis, 54-75. 